\title{
MÜHELY
}

\author{
SZARKA LÁSZLÓ*
}

\section{A közös történelem nehéz öröksége}

\section{Viták nemzet és állam historikumáról}

\begin{abstract}
A magyar történetírásban az elmúlt húsz évben eröteljes kísérletek történtek a poliglott történeti magyar állam multietnikus sajátosságainak reális újraértelmezésére. Ez részben a modern nacionalizmuselméletek historiográfiai lecsapódásának, részben a modern, posztmodern nemzeti és (nemzet)állami történeti narratívák át-, illetve kialakításának a következménye volt. Az európai történetírásban mindenütt megfigyelhető folyamatban többféle célképzet fogalmazódott meg. A nacionalizmusok történeti, politikai, nyelvi, etnikai forrásvidékeinek feltérképezésétől, a nemzet- és államépítő nacionalizmusok pozitív és negatív funkcióinak elemzésén, a nemzeti mítoszok kritikáján, tényleges szerepük értékelésén át egészen a nemzetközpontú történelemképek lebontásáig, átfogalmazásáig terjednek ezek a törekvések. ${ }^{1}$
\end{abstract}

\footnotetext{
* Szarka László, MTA BTK Történettudományi Intézet / Selye János Egyetem Pedagógiai Kar Történelem Tanszék, Budapest/Komárom, tudományos fömunkatárs /docens, szarka.laszlo@btk.mta.hu

${ }^{1}$ A nemzetközpontú történetírás történeti funkcióját, dilemmáit és ellenmondásait jól foglalta össze Fuglestad, Fin: The Ambiguities of History: The Problem of Ethnocentrism in Historical Writing. Academic Press, Oslo 2005. A magyar történeti irodalomban Gyáni Gábor: A mai magyar történetírás dilemmái. In: Uő Relatív történelem. Budapest, Typotex, 2007. 285-290; Szabó Miklós: Politikai kultúra Magyarországon 1896-1986. Budapest, Atlantis, 1989. 236-237. Újabban Kántor Zoltán munkái jelzik a modern magyar nemzeti társadalom kialakulásában a kétféle - nyugatias típusú állami, politikai alapozású, illetve a keleties, etnikai, nyelvi, kulturális - nacionalizmusok együttes hatását. Kántor Zoltán: Szöveggyüjtemény a nemzeti kisebbségekröl. Budapest, Rejtjel Kiadó, 2005. 45-
}

REGIO 22. évf. (2014) 1. szám. 156-192. 
A magyar történetírásban jeles elődök foglalkoztak behatóan a Magyarországon honos nemzeti közösségekkel, akiket a magyar historiográfiai tradíció nagyvonalúan egységesen nemzetiségként kezel. Maga Szekfü Gyula is fontosnak tartotta például, hogy a 1819. századi nyelvharcok forrásait közreadja, a Magyar történet pedig végigköveti a nem magyar népek történetét. A román nemzeti fejlödést vizsgálva Miskolczy Gyula, Jancsó Benedek, Mikó Imre, Makkai László, vagy éppen Mályusz Elemér, Bíró Sándor, Mester Miklós ugyan más-más eredményekre jutottak, de a román nemzeti mozgalom jelentőségét, létjogosultságát nem vitatták. A szlovák, szerb, rutén nemzetfejlődést bemutató Czambel Samu, Steier Lajos, illetve Thim József, Hodinka Antal számára a magyarországi szláv nemzetiségek létezése, létjogosultsága magától értetődő volt. A pártállami korszak 19-20. századi nemzetiségtörténeti föirányát jelentő I. Tóth Zoltán, Csatári Dániel, Arató Endre, Niederhauser Emil, Tilkovszky Loránt munkái pedig a szomszéd marxisták által is többé-kevésbé elfogadott értelmezési kereteket alakítottak ki. Az előző generációk munkásságát az elmúlt huszonöt évben kiváló szerzők - példaként említsük meg Miskolczy Ambrus, Demmel József, Sokcsevits Dénes, Juhász József, Ábrahám Barna, Halász Iván, Ress Imre nevétkönyvei, tanulmányai folytatták. És persze a szomszéd országok történészei (például Adrian Rusu, Lucian Boia, Dušan Kováč, Elena Mannová, Igor Grdina, Oto Luthar, Miroslav Hroch) ma már gyakran a magyar szerzőknél is hangsúlyosabban jelen vannak a középeurópai diskurzusokban. Miközben otthon ők is a miénkhez hasonló kihívásokkal szembesülnek. Egyszerre próbálják meg a mindenkori nemzet(iség) és állam(iság) valóságos historikuma és a mai nemzetállami igények felől értelmezni az évszázadokon átívelő nemzetépítési folyamatokat. Az egymásra figyelés, együtt gondolkodás nélkül azonban aligha haladható meg végleg a „történelmi” és „történelem nélküli”, vagy éppen a teljes és csonka társadalmi szerkezetü, szomszédjainknál pedig az „elnyomó” és elnyomott’” népek, nemzetek leegyszerüsítő kategorizációja, és a mögötte meghúzódó történeti

48. A kétféle nacionalizmus elméleti különbségeiről és gyakorlati egybefonódásáról ld. Plamenat, John: A nacionalizmus két típusa. In: Bretter Zoltán - Deák Ágnes (szerk.): Eszmék a politikában: a nacionalizmus. Pécs, Tanulmány Kiadó, 1995. 56-57.

REGIO 22. évf. (2014) 1. szám. 156-192. 
mítoszok politikailag mindig könnyen tematizálható kizárólagossága, az elöítéletek egymással szembeállító funkciója.

Az integrálódó európai uniós szerkezet és a nemzetállami keretek közötti, 21. század eleji párhuzamos és ambivalens viszonyai közt a kettős beszéd sajátos leleményeire támaszkodva ismét erőteljes nemzeti diskurzusok, politikai (szub)kultúrák épülnek. Ezért is jelent komoly kihívást a (poszt)modern nacionalizmus történeti elöképeinek és előzményeinek tisztázása. Riogatásnak tünhet, de lassan hétköznapi valóssággá válik a (poszt)modern nemzetállam és a neonacionalizmusok sajátos összefonódásának a veszélye. A „történeti nemzetek” közvéleményében például ismét divat lett a 19. századi nemzeti romantika aranykorára hivatkozni - kivált az alkalmazott történelem (,public history”) és a politika által tematizált köztörténet szintjein. Ugyanezt a funkciót tölti be a „történelem nélküli nemzetek” mártíriuma: az „ezeréves elnyomások” mítoszai ugyancsak képesek hadrendbe állítani a neonacionalista programokkal induló pártok választói bázisát. Az Unióban pedig könnyü megtalálni a közös ellenségképet.

Elméleti szinten persze mindig könnyebb eljutni arra a felismerésre, $\mathrm{s}$ belátni annak valószínüségét, hogy térségünk történetiállami alapozású nacionalizmusainak modern polgári nemzeti ideológiákká való átalakításában éppúgy szükség volt a nyelvi, kulturális közösségek mozgósítására, a polgári elitek megnyerésére, mint az önálló állami tradíciókkal nem, vagy csak részben rendelkező népek nemzetépítésének. A magukat egymáshoz képest meghatározó és időben, térben, jogokban saját maguk birtokát kijelölő nacionalizmusok párhuzamosságai, rokon vonásai erősebbek, mint a köztük lévő különbségek.

Paradox módon az etnocentrikus történeti konstrukciók meghaladásának szakmai igénye az elmúlt negyedszázadban akkor fogalmazódott meg, amikor ezzel egy időben a neonacionalizmusok ismét az „örök nemzet” ahistorikus és anakronisztikus fogalomrendszerét állították be érvelésük tengelyébe. Ekkor kezdett felerösödni a térség történetírásaiban a „mítoszmentesítésnek”, a nemzeti legendáriumok kritikai elutasításának a tendenciája.

REGIO 22. évf. (2014) 1. szám. 156-192. 


\section{A közös múlt olvasatai}

Az óhatatlanul konfliktusos nemzetközpontú történelemszemlélet túlkapásainak meghaladásában hasznos eszköz lehet a magukat egymáshoz képest meghatározó nemzetek „közös múltjáról” közösen készített elemzés. A közös múltértelmezések kiemelt fontosságú próbálkozásaiként egyre gyakrabban jelennek meg a közös történelemtankönyvek, közös összefoglalások megírását célzó kísérletek. A kelet-közép-európai térségben a cseh-német, lengyel-német kísérletekkel egy időben látott napvilágot Kárpátaljáról a magyar-ukrán közös összefoglaló munka. ${ }^{2}$ A Magyar-Szlovák Vegyes Bizottság az elmúlt másfél évtizedben több közös város-, identitás- és egyháztörténeti tanulmánykötetet adott közre. ${ }^{3} 2013$ végére ugyanennek a bizottságnak a jóvoltából elkészült a magyar-szlovák közös múlt kulcskérdéseinek párhuzamos értelmezéseit bemutató kötet kézirata is. ${ }^{4}$ A kötet kétféle nyelvi változatát három-három magyar és szlovák történész lektorálta. ${ }^{5}$

${ }^{2}$ Fedinec Csilla - Vehes Mikola (szerk.): Kárpátalja 1919-2009: történelem, politika, kultúra. Budapest, Argumentum, 2009; Ugyanez ukránul: М. Вегеш Ч. Фединець (eds.): Закарпаття 1919-2009 років: історія, політика, культура. Ужгород, Видавництво «Ліра», 2010.

3 A Bizottság munkájának eredményeképpen jelent meg pl. Csukovits Enikő Lengyel Tünde (szerk.): Bártfától Pozsonyig. Városok a 13-17. században. Budapest, MTA TTI, 2005. Ugyanez szlovákul: Csukovits Enikő - Lengyel Tünde (red.): Z Bardejova do Prešporku. Spoločnost' súdnictvo a vzdelanost'v mestách v. 13.-17. storočí. Prešov-Bratislava, 2005; Štefan Šutaj - Szarka László (red.): Regionálna a národná identita v mad’arskej a slovenskej histórii 18.-20. storočia = Regionális és nemzeti identitásformák a 18-20. századi magyar és a szlovák történelemben. (Historia Slovaca-Hungarica - HungaroSlovaca 1.) Prešov: Universum, 2007; Balogh Margit (szerk.): Felekezetek, egyházpolitika, identitás Magyarországon és Szlovákiában 1945 után = Konfesie, cirkevná politika, identita na Slovensku a v Mad'arsku po roku 1945. (Ford. Avar Hajnalka, Galina Šándorová.) (Historia Slovaco-Hungarica Hungaro-Slovaca 2.) Budapest, Kossuth, 2008.

4 A Magyar-Szlovák Történész Vegyes Bizottság önálló kezdeményezésére 2007-ben elkezdődött, majd 2009-től kormányzat által is támogatott munka célja a közös múlt különböző értelmezéseit bemutató kézikönyv megírása, amely 16 kulcskérdést emelt ki. A 2013-ra elkészült kézirat címe: Közép-európai párhuzamok és konfliktusok. A közös múlt a magyar és a szlovák történelemben. A tervek szerint szlovákul és magyarul azonos szöveggel egy időben megjelenő

REGIO 22. évf. (2014) 1. szám. 156-192. 
Miközben tehát sorra jelennek meg a térség történészeinek a nemzeti látószöget és az etnocentrikus szempontokat árnyalni, a „másik” szempontjait is érzékeltetni kívánó közös munkái, minden érintett országban magától értetődően sokféle ellenvélemény is megjelenik. 2013 decemberében a Hitelben, illetve a Magyar Hüperion című kiadványban, a ,jobboldali értelmiség folyóiratában” például nagyjából egy időben két figyelemre méltó tanulmány jelent meg a szlovák-magyar történeti viszony radikális átértelmezésének igényével. ${ }^{6}$

Tőkéczki Lászlónak a Hitelben közreadott rövid tanulmányának kiindulópontjai a következő állítások: a szlovák történetírás utólag kívánja létrehozni az önálló szlovák nemzeti történelmet; a szlovákság etnikailag hosszú évszázadokon keresztül a szlávság, állami hovatartozását tekintve a Magyar Királyság része volt. Tőkéczki Balassa Zoltán kassai magyar értelmiséginek a szlovák történelem kizárólagos magyar olvasatát kínáló munkájára hivatkoz-

munka előtörténetéről, a kötet elkészítésével kapcsolatos túlzott várakozásokról és a közös munkálat ellen irányuló politikai támadásokról ld. Šutaj, Štefan: Szlovák-magyar történelmi párhuzamok és konfliktusok (a nemzeti történelmek közép-európai kontextusban) avagy a közös szlovák-magyar szövegek írásáról. In: Korridor, 2014/1. http://korridor.eu/issue/elso-evfolyam-2014-1-szam/

${ }^{5}$ Az elkészült kéziratról két másik felkért történésszel együtt Tökéczki László is lektori véleményt készített. A kötet megjelenését nem támogató, részletes negatív lektori jelentésének summájaként leszögezte, hogy azért nem támogatja a kézirat megjelentetését, mert a magyar és a szlovák szerzők álláspontjai közti távolság tudomásulvételével „mi legitimálnánk a szlovák hazugságokat”. Elsősorban a szlovák nemzetépítéshez kapcsolódó történelemfelfogást, a modern szlovák nemzetépítő nacionalizmus kötetben is megjelenő narratívát bírálta.

${ }^{6}$ Tőkéczki László: Egy posztmodern nemzetépítés és identitás alakítás Európa közepén. In: Hitel 2013/12. 69-72.

http://www.hitelfolyoirat.hu/sites/default/files/pdf/10-tokeczki.pdf;

Tőkéczkivel azonos regiszterben az egész szlovák történetírást a hazugságban találja vétkesnek Farkas Géza, Pozsonyból hazahívott egykori magyar diplomata: „A hivatalos Magyarország nem mer kézre eső csodafegyveréhez, a tényekhez nyúlni, nem fordítja elönyünkre azt az adottságunkat, hogy nekünk nem kell új történelmet írnunk, vagy átírnunk a régit.” Farkas Géza: Szlovákia-ügy. Rendhagyó megfontolások. In: Magyar Hüperion, 2013. Digitálisan elérhető a felvidéki hírportálon:

http://www.felvidek.ma/images/stories/_esemenyek/2014/02/MH_II_1_Farkas_ G._2.pdf

REGIO 22. évf. (2014) 1. szám. 156-192. 
va kénytelen maga is rádöbbeni arra, ami a szlovák történetírás számára immár hosszabb ideje alaptétel. ${ }^{7}$

Éppen a magyar államiság, s azon belül a felsőmagyarországi régió megyéi jelentették a szlovákság etnikai, kulturális, nyelvi különfejlődésének ezeréves külön kereteit, vagy ahogyan Dušan Kováč magyarul is megjelent egykötetes szlovák történeti összefoglalója is egyértelmüen megfogalmazta: „A történeti magyar állam létezése megteremtette a szlovák nemzet kialakulásának alapvető feltételeit. A szláv etnikum már a 9. század folyamán elkezdett differenciálódni. [...] A szlovákok különálló etnikumként a történeti magyar állam keretei közt fejlődtek, míg a lengyelek és a csehek a lengyel és a cseh királyság keretei közt. A magyarországi szlovákok közt is jelentős nyelvi különbségek voltak, több dialektus nagymértékben különbözött egymástól, s ezek a különbségek idővel még tovább nőttek. Az egységesülést viszont a zárt területen kialakult kompakt települtség segítette elő.",

A szlovákság megkésett nemzetfejlődésének okairól Tőkéczki László a következő hiánykatalógust állította fel. Nem volt szlovák területi, állami különállás, nem volt szlovák nemesség, iskola, a régió városait és vonzáskörzeteiket pedig németek lakták. A latinitás szerinte kizárólag a magyar identitás fejlődésének kedvezett. Ráadásul a szlovák társadalom mindig is csonka maradt, saját nemesi réteg nélkül. Így azután „egy világtörténelmi véletlennek” „egy átmeneti erőviszonyrendszernek”, ,egy tényleg alaptalan, átmeneti szerencsének" köszönhetően kialakult Csehszlovákia. Majd az abból kiváló Szlovákia történészei „folyamatosan területi alapon lopnak maguknak történeti figurákat”. Szerencsére a marxista korszak szlovák történetírásának rövidlátó és nacionalista, dehungarizációs koncepciója mára már jórészt a múlté. A szomszédok nemzetépítését mindenestül rosszalló magyar történészben azonban rögzültek a szlovák nemzetépítéssel szembeni reflexek. Szerinte „a cseh ügyeskedés” által a Magyar Királyságból „kiszakított” szlovákság számára a magyar ellenségképben testet öltő negativitás jelenti a ,sok hiányzó

\footnotetext{
${ }^{7}$ A hivatkozott könyv Balassa Zoltán: Két nemzet a Kárpát-medencében. A szlovákok története. Kassa-Budapest, 2009. (magánkiadás)

${ }^{8}$ Kováč, Dušan: Szlovákia története. Pozsony, Kalligram 2001. 51.
}

REGIO 22. évf. (2014) 1. szám. 156-192. 
történelmi előzmény mindent pótló eszközeként" a legfontosabb identitásképző tényezőt. ${ }^{9}$

Nemcsak a szlovák történetírás, hanem egyebek közt a magyar szlavisztika is sok száz bizonyítékot halmozott fel arról, hogy a magyarországi szlovákok nyelvi megnyilatkozásaiban is folyamatos fejlődés volt tapasztalható a latinitás évszázadai alatt, s nem véletlenül tudtak élni az oktatási, kulturális, egyházi karrierlehetőségekkel, a nagyszombati egyetem, a pozsonyi, a lőcsei, a késmárki, az eperjesi, de még a győri, brassói evangélikus skóláknak is mindig voltak jeles szlovák végzösei.

Persze, amint kicsit is belegondol Tökéczki László a felföldi világ tényleges etnikai és konfesszionális viszonyaiba, rögtön kénytelen maga is meglátni az evangélikus szlovákság szlovakizált cseh bibliai nyelven már a 16-17. században megjelenő irodalmát, iskoláit, népi és „magas kultúráját”: „Az evangélikus kollégiumok »multikulturális« közegében (szlovák, német, magyar) megszülethetett a »szlovák nemzet eszméje«, vagyis az, hogy a Magyar Királyság felső-magyarországi szlávjai egy "polgári« nemzetet alkotnak. Ehhez ismét a magyar vezetésü evangélikus egyház tehetségre alapozó nemzetközi ösztöndíjrendszerére volt szükség. A világhírü német egyetemekre kikerülő felvidéki szláv tehetségek szülik meg a szlovák nemzetet. Sajnos a magyarellenesség jegyében, holott ez nem volt »szükségszerü«. Mégpedig azért nem, mivel a két-, illetve háromnyelvüség tradicionális világában nem kellett élére állítani az együttélési viszonylatokat. A megszülető tót nemzet ugyanis ugyanúgy együtt élhetett volna a magyarokkal és németekkel, mint ahogyan elődei tették évszázadokon át." ${ }^{10}$ (Kiemelés az eredetiben - Sz. L.)

A „tót” nemzetépítés szerinte tehát alapvetően magyar és német hatásra kezdődött, ami a nacionalizmusok természetrajzából kiindulva magától értetődő. A tradicionális „együttélési viszonyok” idealizált képlete viszont annak a bokrétás magyar történelemszemléletnek a jámbor óhajtása, amely a „Legyen úgy, mint régen vót!” jegyében szeretné előre és visszamenően átrendezni a Kárpátmedence történetét.

\footnotetext{
${ }^{9}$ Tökéczki László: Egy posztmodern nemzetépítés, i. m. 70.

${ }^{10}$ Uo. 71.
}

REGIO 22. évf. (2014) 1. szám. 156-192. 
A felföldi magyar nemesség jelentős részének szlovák anyanyelvüsége pedig olyan evidencia, amelyben kételkedni rendszerint csak az egynyelvü magyar álomvilágban élő rajongók szoktak. Legújabban a Justhok kapcsán Demmel József mutat rá a felföldi szlovák nemesség szerteágazó családi, kulturális és gazdasági hálózatainak müködésére. ${ }^{11}$

Tőkéczki László önmaga részleges megvilágosulását egy másik felismerése így rögzíti: „A mai szlovákságnak ilyen körülmények közt kőkemény és becsületes hivatkozási alapja lehetne az a népietnográfikus alap, amely kétségtelenül mindig fennállt FelsőMagyarország egyes régióiban.”12 A nemzetépítő nacionalizmusok mindig is saját hozott történeti anyagukból alkotják meg a „nemzeti tereket”: ez lehet akár egy történeti, akár egy mai állam területe, akár pedig egy történeti mítosz, vagy éppen az etnikai határok által körülrajzolható legtágasabb „nemzeti világ”. Térségünk valamennyi nemzeti történetírása immár lassan kétszáz éve alapvetően saját nemzete és állama történetét írja. Ebben a tekintetben nincs köztünk különbség. Az akadémiai szlovák történetírás - bár örökzöld vitákat folytat a 18-20. századi népesség-összeírások, népszámlálások adatainak értelmezéséröl - pontosan látja a 20. századi és a mai Szlovákia etnikai szerkezetének valamennyi sajátosságát, köztük a délszlovákiai magyarság ismét rendkívül rendkívüli mértékben felgyorsult migrációs és asszimilációs fogyásának folyamatát is. Az azonban erősen egyoldalú olvasat Tőkéczki László részéről, hogy a szlovák történetírás a Csehszlovákiához került magyar többségü régiói, városai miatt kényszerül utólagos múltteremtésre. ${ }^{13}$

11 Demmel József: Pánszlávok a kastélyban. Justh József és a szlovák nyelvü magyar nemesség elfeledett története. Budapest, Kalligram, 2014.

12 Tőkéczki László: Egy posztmodern nemzetépítés, i. m. 70.

13 „De őket (ti. a szlovákokat - Sz. L.) egy világtörténelmi véletlen, vagyis átmeneti erőviszonyrendszer olyan területekhez is juttatta az I. világháború végén, amelyhez az akkorra már kialakult valódi szlovák népiségnek sem volt soha semmi köze, s így még inkább rászorultak az utólagos múltteremtésre. Most már a saját valódi történelmen túl is hamisítani kell - minden áron. Hiszen így, enélkül hogyan lehetne identitást teremteni például olyan, a történelmi múltban karakteresen nem szláv városokra nézve, ahol a későbbi valódi szlovák jelenlét finoman szólva is alárendelt - akkor is, amikorra végre tényleg kialakult az, amit szlovákságnak lehetett nevezni (pl. Pozsony, Kassa). Nem egészen érti az ember,

REGIO 22. évf. (2014) 1. szám. 156-192. 
Természetesen tisztában vagyok a család- és helynévátírás szlovák helyesírási szótárban is kodifikált gyakorlatának célzatosságával. Annak idején a vegyes bizottságban mindent elkövettünk a bevezetése ellen, de végül az Erdély-történet kapcsán kialakult román-magyar vita utáni hangulatban, a korabeli magyar állami hatóságok és akadémiai fórumok nem adtak támogatást szakmai kezdeményezésünknek. ${ }^{14}$ Mint ahogy az is jól látható, hogy a mai szlovák történetírásban is jelen vannak azok a nacionalista tendenciák, amelyek a hasonló magyar törekvésekkel párhuzamosan igyekeznek alapjaiban megkérdőjelezni a másik nemzet történeti létjogosultságát.

Az egész szlovák nemzetépítést, benne az egész szlovák történetírással ezzel együtt, meggyőződésem szerint, súlyos hiba olyan vádakkal támadni és elmarasztalni, miként azt Tőkéczki László teszi. Szerinte a szlovák nemzetépítés a történetietlen hazugságokra épül. Mindez a mai „antinacionális és kozmopolita világban” oda vezet, hogy „nem a hazugság a bün, hanem annak leleplezése”. „S ezért nehéz az igazság »nemzetek feletti« szakmai szolgálata is, hiszen a szlovák hazudozások minden nehézség nélkül beolvadnak a »liberális« történelmi hazudozásokba (»narratíva «)." 15

Kérdés persze, hogy mi mindent sorol a szerző ez utóbbi kategóriába. Ha jól olvassuk, akkor a magyarországi nem magyarok nemzetté válása teljes egészében ide tartozik, együtt a nyelv és az etnikum nemzetformáló szerepével. Láthatóan úgy gondolja, hogy azok „a bármiféle szlávok”, akik az egykori „magyar állam/királyság állampolgárai voltak”, s akik számára a Magyar Királyságban „saját nemzeti életük kisközösségi formáit nem akadályozták”, valójában ma is magyarok: „A szlovákságnak valójában az a baja, hogy tudatlanul is tudja egykori »magyar világát «, s ettől fél. A történelmet nem lehet visszaforgatni, s így nem szabad megengedniük a tárgy-

hogy miért nem lehet egy tényleg alaptalan, átmeneti szerencsét közösségileg megérteni és megemészteni.” Uo.

${ }^{14}$ A Magyar-Csehszlovák Történész Vegyesbizottság magyar tagozatának állásfoglalása a magyar történelmi személynevek szlovák átírására irányuló törekvés tárgyában. In: Magyar és csehszlovák történészek eszmecseréje a régi magyar család- és személynevek, valamint a helynevek írásmódjáról. MagyarCsehszlovák Történész Vegyesbizottság Magyar Tagozata. Budapest, 1988. 7-10.

15 Tőkéczki László: Egy posztmodern nemzetépítés, i. m. 71.

REGIO 22. évf. (2014) 1. szám. 156-192. 
szerüséget! Miért is nem? Azért, mert akkor nincs reményük sem arra, hogy a jogtalanul szerzett magyar etnikumú népet és területét valaha is »bedarálhassák «”. ${ }^{16}$ Mindennek a summája tehát röviden így foglalható össze: ezzel az egyszerre idealizáltan magyar tudatú, ugyanakkor saját államterülete nem szlovák részeit megemészteni nem tudó szlováksággal magyar részről immár vitatkozni sincs értelme. ${ }^{17}$

Tőkéczki László minimális szlovák filológiai, historiográfiai ismeretekre támaszkodó hiperkritikus megközelítése nem annyira a szlovák, mint inkább a mai magyar nemzetépítés történeti argumentációjának gyengéit jelzi. Sok tekintetben produktív, a történelmet nemcsak napjaink valóságos kérdései, hanem a magyar jövőképek felöl alakító történelemszemlélete miatt a szerző (és a lektor) az egész (napjainkig tartó) 20. századi közép-európai történelmet, vélhetően annak minden nemzetállamával együtt „egy világtörténelmi véletlen, vagyis átmeneti erőviszonyrendszer" zsákutcájaként kezeli, amelyből a magyar kiút csak visszafelé vezethet. És ez az a (mély)pont, ahol a jórészt megrögzött elöítéletekre alapozott magyar történeti önkép, a maga minden (rész)igazságával, a nemzeti jövőképek alakítása szempontjából is kritikus irányt vehet, s ahol nincs többé értelme újabb megvilágosodásokra várni. Módszertanilag pedig nehezen menthető hibája ennek és minden hasonló etnocentrikus felfogású, nyíltsisakos támadó hadmüveletnek az, hogy árnyékra vetődik. A magyarhoz hasonlóan a mai modern szlovák történetírás is sokféleképpen tagolt képlet, amelynek akadémiaiegyetemi, alkalmazott történeti és politikának alárendelt köztörténeti szintjein a posztnacionális, posztmarxista, posztmodern áramlatok mellett tartósan jelen vannak a nemzetközpontú, regionális megközelítések, az analitikus mikrotörténet, a nacionalista kizárólagosság

\footnotetext{
${ }^{16}$ Uo.

${ }^{17}$ Tőkéczki László remélhetően egyszervolt szlovák történeti-lektori kirohanásának értelmét és végső célját százpontos slusszpoénnal imígyen zárja le: „A »kibékülős magyar, progresszív« történészeket pedig hagyjuk, hogy közlekedjenek Jászi Oszkár (Károlyi Mihály stb.) régi zsákutcájában. Tulajdonképpen a feladat az volna, hogy őket tegyük a helyükre, hiszen a később születés kegyelméből erre már minden rendelkezésre áll. Északi szomszédainkat ma még úgysem téríthetjük észhez, számukra ugyanis a múlt csak egy alakítható sztrapacskanyersanyag. Pedig azt kár elrontani!” Uo.
}

REGIO 22. évf. (2014) 1. szám. 156-192. 
különböző áramlatai. Örök hibája a végeláthatatlan szomszédságtörténeti vitáinknak, hogy miközben a szomszédok szélsőséges álláspontjait bíráljuk, éppúgy az egész szlovák, román, szerb stb. történetírásra kiterjesztjük elítélő véleményünket, mint ahogy a szomszédországi kritikusok is gyakran teszik ezt a mai magyar történetírással. ${ }^{18}$

\section{Történelem, nemzeti emlékezet - történelempolitika}

Kelet-Közép-Európa 19. századi párhuzamos nemzetépítő nacionalizmusainak mindent átható dikciója után a 20. században sem mindig a kutatások belső logikája, hanem gyakran a nemzetállami történelempolitika jelölte ki a történettudomány irányait és feladatait. Ennek legfőbb okát abban jelölhetjük meg, hogy a nemzet és az állam történelme - amely szinte magától értetődően lett az elmúlt két évszázad historiográfiájának legfőbb vizsgálati objektuma - a nyelv és a kultúra, illetve az állampolgárság és a jogrend mellett a nemzet legfontosabb integráló erejének, legitimációs tényezőjének számít. Gyáni Gábor szerint a 19. század elején tudományos diszciplínává fejlődött történetírás tudatosan választotta elemzései legfontosabb tárgyának a nemzetet és a nemzetállamot, hiszen azok egyszerre jelentették az emberi közösség megismerésének, befolyásolásának és a történész számára is fontos visszajelzéseknek az optimális keretét. Ráadásul a mecénás állam mindennapi ideológiai, történelempolitikai szükségletei is abba az irányba szorítják a történészeket, hogy az állam mai igényei mentén értelmezzék újra a múltat. ${ }^{19}$

${ }^{18}$ Ennek a folyamatos polémiának a közelmúltban lezajlott véleménycseréjéről ld. Holec, Roman: Trianoni rituálék, avagy gondolatok a magyar historiográfia egyes jelenségeiről. In: Fórum - Társadalomtudományi Szemle, (12) 2011. 4. 109-132; Zahorán Csaba: a Trianon-jelenség pozsonyi tükörben. Válasz Roman Holec Trianoni rituálék, avagy gondolatok a magyar historiográfia egyes jelenségeiről címü cikkére. In: Historický časopis, 58. évf. 2010. 2. sz. 291-312; Szarka László: Párhuzamos jelenségek a magyar és szlovák történetírásban, köztörténetben. In: Történelmi Szemle, (54.) 2012. 3. 469-490.

19 „A történetírás magának vindikálja tehát a jogot, hogy a nemzeti múlt kapcsán a mának szóló magasztos, ideálként soha szem elől nem téveszthető erkölcsi és politikai mondanivalót megfogalmazza a jelen számára. A történetírás ilyenformán arra hivatott, hogy többnyire - talán csak implicit, de olykor bizony nagyon is explicit módon - igazolja a modern nemzetállamok korukbeli létjogosultságát.

REGIO 22. évf. (2014) 1. szám. 156-192. 
Aligha véletlen, hogy a nemzetek fejlődése - az etnogenezis, a nemzetek születésének mítoszokba vesző történetétől a modern nemzet- és államépítő nacionalizmusok müködéséig terjedően - ma is nélkülözhetetlen kötőanyaga a nemzeti identitásoknak. A mítoszok és az általuk, bennük rögzült történetek a nemzeti emlékezet ősi rétegeit, az időközben megszünt nemzeti királyságok, fejedelemségek pedig az egymásnak feszülő nemzetállamok történeti előzményeit, az elsőbbség, a dominancia bizonyítékait, a folytonosság szimbólumkészletének forrását jelentik. A törzsi, nemzetségi, rendi, állampolgársági, nyelvi, politikai nemzetkonstrukciók így válhatnak az „örök nemzet” különböző, gyakran egészen más entitásokat jelölő létformáivá. S ez a nemzeti megközelítés magyarázza azt is, hogy például az univerzális keresztény müveltség épített és szellemi öröksége, vagy a nyugati civilizáció mühelyeiként, védőpajzsaiként szolgáló várak és városok, templomok és kolostorok miért lesznek rendre egyik vagy másik nemzet kizárólagos emlékezeti helyeivé, miközben - a térség eredendő soknyelvüsége és a latinitás nyolcszáz éves uralma révén - a valóságban többségük az itt élő népek közös múltjának, közös örökségének emlékét hordozza.

A 21. század eleji magyar és szlovák történészek is egyre többször szembesülnek a köztörténetben gazdag táptalajra talált nemzeti mítoszok továbbélésével, tudatformáló hatásával. Kiváló elemzések egyszerre próbálták a mítosz müködésének módját, rendjét, funkcióját megérteni és a maguk helyére tenni, ugyanakkor szigorú szakmai kritikával hatástalanítani is a különbözö teorémákat, az önbecsapásra alkalmas legendákat, a mások létezésének, létjogosultságának megkérdőjelezéséig elvezető tévképzeteket. ${ }^{20}$

Ezt a feladatot azzal teljesíti, hogy a jelen nemzeti realitásai mögé oda rajzolja a távoli, egyúttal időben folyamatos, a jelenbeli állapotokat megelőlegező, sőt abba szükségszerúen torkolló (oda tartó) eseményeket és folyamatokat. Ez így maga a történelem, legalábbis ahogyan a történetírás sugalmazza.” Gyáni Gábor: Kollektív emlékezet vagy történetírás? Mire emlékszünk?

A közösségi memória szelektivitása Magyarországon és a nagyvilágban. A Történelemtanárok Egyletének országos konferenciája.

http://www.tte.hu/toertenelemtanitas/toertenelemtanarok-orszagos-

konferenciaja/7843-gyani-gabor-kollektiv-emlekezet-vagy-toertenetiras (Letöltve: 2014. február 8.)

${ }^{20}$ A nacionalista mítoszok, hamis legendák, etnikai sztereotípiák elemzése mindkét történetírásban külön-külön és közösen is elkezdődött. Szlovák részröl kiváló

REGIO 22. évf. (2014) 1. szám. 156-192. 
A nemzetállami szembenállásokat lezárni hivatott európai integráció 21. század eleji évtizedeiben a történeti (mester)narratívák jelentős fáziskéséssel követik a nemzetek közötti együttmüködésre épülő európai és világtendenciákat. A sok szempontból közös középeurópai történeti - állami, dinasztikus, egyházi, kulturális stb. örökség közös feldolgozása ismét időszerüvé vált. Az európai egység megteremtésében elkötelezett államok és nemzetek közös politikai, katonai keretek közt élnek. A száz-kétszáz éven át nemzetállami bezártsághoz szokott nemzeti társadalmaink számára megkerülhetetlen a minden korábbinál átfogóbb, őszintébb együttmüködés. A múltbéli konfliktusokat megoldó megbékélési folyamatokban azonban még mindig sok gondot okoznak az etnocentrikus kisajátítás reflexei, a nemzeti történetírás atavisztikus megközelítései.

A végtelenített magyar-szlovák viták egyik kiútkeresési gyakorlatának számít a nemzetközpontú fogalmak lecserélésére irányuló szándék. Az Uhorsko - Magyar Királyság, Slovensko - Felvidék fogalmi dichotómiák mögött az adott kor eltérő nemzeti reprezentációi és pozíciói húzódnak meg, amelyek szükségképpen más-más megközelítésböl, perspektívából jelölik meg az államot, régiót. A nemzeti önmegjelölés, önkép és önzés nemzetközi gyakorlatában az állam hivatalos neve Közép-Európában - Svájc, Liechtenstein, Koszovó, Bosznia-Hercegovina, Moldova példáival ellentétben - a többségi nemzetek nevével azonos. Az osztrákok esetében pedig maga az ország adott nevet a nemzetnek. Az időközben megszünt, soknemzetiségü történeti államalakulatok helyén létrejött új nemzetállamok azonban saját nevüket az etnogenezisig, sőt azon túl is viszszavezetve a nemzeti térkijelölés gyakorlatát követik, s ezzel átírják a történeti reáliákat. Az 1918 előtti Magyar Királyság megnevezésére a többi „honos nemzetiséghez” hasonlóan a szlovákok ugyan saját

összképet nyújt Krekovič, Eduard - Mannová, Elena - Krekovičová, Eva (red.): Mýty naše slovenské. Bratislava, AEP, 2005. Magyar részről ld. pl. Romsics Ignác (szerk.): Mítoszok, legendák, tévhitek a 20. századi magyar történelemröl. Budapest, Osiris, 2003; Ablonczy Balázs: Trianon-legendák. Budapest, Jaffa Kiadó, 2010. A Magyar-Szlovák Történész Bizottság 2011. évi komáromi ülésszakán elkezdett közös munka eredményeit közli Dudeková, Gabriela: Etnické stereotypy v historickom výskume. Forum Historiae, 2012/2. http://forumhistoriae.sk/02-2012 (Letöltve: 2014. február 18.)

REGIO 22. évf. (2014) 1. szám. 156-192. 
megnevezésüket („Uhorsko”) használták, de nem volt kétséges, hogy ez a megnevezés a Magyar Királyságot jelentette.

Vörös László fogalomkritikai elemzése ${ }^{21}$ igen pontosan mutatja be azt, hogy a Csehszlovákia részeként államjogi értelemben is lehatárolt Szlovákia területét, azaz az 1918 előtti közös magyar állam északi megyéinek trianoni határokkal elkülönített részét - örök nemzeti területként elképzelve - visszamenőleges hatállyal magától értetődően Szlovákia névvel illetik. A magyar történetírás pedig az 1918 előtti és utáni Magyar Királyság jogfolytonosságára és névazonosságára hagyatkozva a két államalakulat közötti területi különbségeket a Királyság kétharmados területveszteségeként határozza meg. A megoldás a közigazgatási, földrajzi vagy etnikai régió nevének megadásában vagy a nemzetiségi sajátosságot kiemelő „felsőmagyarországi szlovák régió” vagy a kissé körülményes, de sokszor semmivel sem pótolható „,a mai Szlovákia területe” kifejezés használata lehet. Az 1918 előtti Magyar Királyság esetében vagy a „történeti Magyarország”, vagy az adott korra utaló jelzős - „három részre osztott”: „királyi”, „reformkori”, „dualizmuskori” Magyarország szerkezetek használatával lehetne kölcsönösen elfogadható megoldást találni.

${ }^{21}$ Vörös László: Analytická koncepcia versus národné dejiny „Národ” ako sociálna reprezentácia. Pisa, Pisa University, 2009. 60.; A felső-magyarországi történeti régió, illetve a szlovák etnikai régió és a 19. századi Felvidék-fogalmak müvelődéstörténeti, politikai jelentésváltozataira ld. Szarka László: Felföld, Felvidék, Szláv Kerület - Slovensko. Adalékok a felföldi magyar-szlovák nemzeti térkijelölés XVIII-XIX. századi történetéhez. In: Papp Richárd - Szarka László (szerk.): Bennünk élö múltjaink. Történelmi tudat - kulturális emlékezet. Zenta, Vajdasági Magyar Mủvelődési Intézet, 2008. 143-161. http://adattar.vmmi.org/konyvek/94/4_a_nemzeti_ter_tortenelmi_reprezentacioi. pdf (Letöltve: 2014. február 10.) A történeti terminológiai terén folyó együttmüködés eddig legfontosabb eredménye: Ábrahám Barna (szerk.): Magyar-szlovák terminológiai kérdések. (Pons Strigoniensis Studia IX.) Esztergom - Piliscsaba, Pázmány Péter Katolikus Egyetem, 2008.

REGIO 22. évf. (2014) 1. szám. 156-192. 


\section{Nemzet, állam - nemzetállam}

A közép-európai történészek, némi túlzással, Anonymus Gestája óta a különböző - törzsi, rendi, polgári, politikai, etnikai - alapokon szerveződő, folytonosan változó, sokak által mégis örökkévalónak tartott nemzetek és a nekik „otthont” adó államok történetét írják. A történetírás mindazonáltal csak a 18. század végén, a 19. század első felében kezdett nemzeti tudománnyá válni, s indult el azon az úton, ahol a nemzet „valóságos historikuma” mellett a történeti kánonokban az aktuális nemzeti erőviszonyok, folyamatok visszavetítése is megjelenik. A mindenkori nemzeti érdekeket kifejező történelempolitikai koncepciók, stratégiák a tudományosság 20. századi nemzetállami mecenatúrájának keretei közt jórészt emiatt keresztezik az „elfogultság és részrehajlás nélküli” „analitikus” kutatások szempontjait. $^{22}$

A magyar és a szlovák történészek útjai részben már 1918 elött különváltak. A magyar történetírás legnagyobb művelői és reprezentatív munkái a reformkortól kezdve a magyar nemzet történetét alapvetően a magyar állam történetével azonosították. A nemzeti romantika Horváth István, Thaly Kálmány által fémjelzett irányzata még az ősi dicsőség, a patetikus hazaszeretet és a nemzeti függetlenség kategóriáiban gondolkodva gyakran rugaszkodott el a történetileg igazolható valóságtól. Az akadémiai keretek közt kibontakozott, pozitivista magyar historiográfia nagy viták árán, de rátalált a Szalay László és Horváth Mihály által kijelölt, a forráskiadásokra és forráskritikára építő nemzeti liberális történelemszemléletre. Pauler Gyula, Fraknói Vilmos, majd Márki Sándor, Marczali Henrik, Szilágyi Sándor nagy történeti összefoglalói a középkori magyar államnak a Habsburg-keretek közötti továbbélését, a vallási és a rendi-nemzeti szabadságért folytatott küzdelmeket bemutatva a nemzet és az állam történetét egymással jórészt azonosították. ${ }^{23}$ A Magyar Királyság multietnikus jellege az ország egyesítő erejének és

\footnotetext{
${ }^{22}$ Erröl egyebek közt Vörös László munkája nyomán bontakozott ki jótékony vita a szlovák történetírásban. Vörös, Ladislav: Analytická historiografia versus národné dejiny: "národ" ako sociálna reprezentácia. Pisa, Pisa University Press, 2010.

${ }^{23}$ Romsics Ignác: Clio büveletében. Magyar történetírás a 19-20. században nemzetközi kitekintéssel. Budapest, Osiris, 2011. 126-135, 152-166.
}

REGIO 22. évf. (2014) 1. szám. 156-192. 
nemzetileg toleráns politikájának bizonyítékaként jelent meg. Az idealizált nemzetiségi politika és az ország nemzetiségeinek békés együttélését kiemelő értékelések mindezt a magyarság eszményi szabadságszeretetére, toleranciájára vezették vissza. ${ }^{24}$

A szlovák vagy szlovák származású, szlovák identitású történetírók egy része a nemzetiségek hozzájárulását is elismerő magyar állameszme kiépítésére törekedett. Például Pechány Adolf, Podhradszky György, Zsilinszky Mihály, Michal Mudroň, Michal Matunák az egységes magyar politikai (értsd: állampolgári) nemzet koncepciójának megfelelően a hungarus örökség ápolását tartották feladatuknak. Elutasították a közös magyar állam történetének nemzetek szerinti utólagos újraértelmezését. ${ }^{25}$ A kiegyezés kori felvidéki

${ }^{24}$ „A magyar nemzet legfőbb törekvése Európa közepén lefolyt ezeréves élete alatt megszakítás nélkül a szabadság kiépítésére és megtartására irányult. Szabadságszerető lévén a meghódított hazában talált idegen nyelvü törzseket nem hajtá szolgaságba, hanem fegyvertársakul és testvérekül fogadta maga mellé. Nemzeti türelmetlenség soha nem volt a magyarnak büne, éppen mert sohasem tört mások felett uralomra, hanem inkább a másokkal közös szabadságra. Innen érthető, hogy a hazában vele együtt lakó törzsek, bár számra felülmúlták őt, soha, még az állam legkritikusabb pillanataiban sem támadtak ellene. Ez a nemzeti türelmesség az oka annak, hogy a magyarság a más törzsekkel nagyon kevéssé keveredett össze és hogy ez utóbbiak nyelvüket és egyéb nemzeti sajátosságaikat akadálytalanul megtartották és kifejlesztették. Mivel nem mások uralmára, hanem inkább a közös szabadságra törekedtek, a magyarok sohasem estek a nemzeti türelmetlenség hibájába.” Horváth Mihálynak Fessler Ignác 1867-ben német nyelven újra kiadott történeti összefoglalójához írt bevezetőjét idézi Szekfü Gyula: A politikai történetírás. In: Hóman Bálint (szerk.): A Magyar történetírás új útjai. Budapest, Magyar Szemle Társaság, 931. 426. Horváth Mihály értelmezését a Fessler-könyv alapján idézi Romsics Ignác. Michael Horváth: Vorwort. In: Geschichte von Ungarn von Ignaz Aurelius Fessler. Leipzig, 1867. Romsics Ignác: Clio büveletében, i. m. 98.

${ }^{25}$ Pechány Adolf, a magyar kormány szláv referenseként 1913-ban közreadott munkájában például így írt erről: „Sasinek Ferenc tót történetíró, mindenáron ki szeretné mutatni, hogy a tótok lakta Felvidék már az Árpádok korában külön hercegséget alkotott, és valamelyik királyi herceg birtokát képezte. Többen Trencséni Csák Mátét is úgy szeretnék feltüntetni, mint tót nemzeti hőst, aki fejedelem módjára uralkodott a Mátyusföldön. Meghisszük, hogy az ilyen magyarázatok beleillenek a tót túlzók politikájába, de a történetet politika kedvéért csinálni nem lehet.”

Pechány Adolf: A magyarországi tótok. Miskolc, Felső-magyarországi Minerva, 2000.

REGIO 22. évf. (2014) 1. szám. 156-192. 
magyarosítás kezdeményezőjeként fellépő Grünwald Bélával vitatkozva a közös történelem értékközösségét mutatja fel Michal Mudroň: „,mióta magyar testvéreink a többi Magyarország-beli nemzetiségekkel, mint egyenjogú társakkal együttesen ezt az országot megalapították és fenntartották, ezen nemzetiségek egyikének sincs külön történelme”. Matunák pedig a cseh-szlovák és lengyelszlovák államkoncepciók jogosultságát tagadva fejtette ki a Magyar Királyság elsődleges fontosságát a szlovákok nemzetté válásában. A 19-20. század fordulójának ellenzéki, a domináns magyar állameszmével és a dualizmus kori asszimilációs felfogással szembeszálló szlovák történészek, társadalomtudósok - mint például František V. Sasinek, Július Botto, Pavol Križko, Ján Lajčiak - az önálló szlovák nemzeti fejlődés szempontjait helyezték munkáik előterébe. ${ }^{26} \mathrm{~A}$ modern nemzetépítő nacionalizmus ideológiájának megteremtésében a történelemnek szintén megkülönböztetett szerepe volt. Botto például, akinek a szlovákok nemzeti tudati fejlődéséről szóló kétkötetes nemzetiségtörténeti munkáját a korabeli magyar hatóságok betiltották, rövid szlovák történeti összefoglalójában a Magyar Királyságon belüli magyar nemzeti dominancia tagadásáig is eljutott. ${ }^{27}$

Velük szemben a felső-magyarországi szlovák régióval foglakozó magyar történészek szinte kizárólagosan a magyarságnak a Magyar Királyság egészére kiterjedő domináns pozícióját tekintették az egyedül elképzelhető vitaalapnak. Grünwald Bélától Iványi Béláig, Steier Lajossal bezárólag azt hangsúlyozták, hogy a magyarság történeti túlsúlya, nemzeti vezető szerepe a felső-magyarországi szlovák régióban is magától értetődőnek számított. ${ }^{28}$

A magyar-szlovák kapcsolatokat, s velük együtt a történetírások közötti viszonyt a 20. század első felében Közép-Európa három nagyhatalmi átalakítása - az I. világháborút lezáró békerendszer,

http://www.sulinet.hu/oroksegtar/data/magyarorszagi_nemzetisegek/szlovakok/a _magyarorszagi_totok/pages/020_pehany_adolf_elatrajza.htm (Letöltve: 2014. február 11.)

${ }^{26}$ Podhradszky György: A tótok lakta Felföld politikai és kultúrgeográfiája (Függelékül a kérdés bibliográfiája). Budapest, Stúdium, 1924.

${ }^{27}$ Botto, Julius: Krátka história Slovákov. Turčiansky Sv. Martin: Knihtlačiarsky účastinársky spolok, 1914

${ }^{28}$ Iványi Béla: Pro Hungaria Superiore. Felsőmagyarországért. Debrecen, Ref. Egyházkerület ny., 1919.

REGIO 22. évf. (2014) 1. szám. 156-192. 
a II. világháborút kirobbantó hitleri Németországhoz kötődő „Neuordnung”, s végül az 1945-1947 között kialakult pax sovietica - határozta meg. Ezek közt a keretek közt a mindenkori „győztes” és „vesztes” nemzetállamok helyzete, akarata, nagyhatalmi kiszolgáltatottsága döntötte el a történelempolitika irányát. A „hosszú 19. század” közép-európai nacionalizmusainak történeti fejlődése az 1919. májusi német, 1919. szeptemberi osztrák és az 1920. júniusi magyar békeszerződésekkel új szakaszába jutott. Ezek a változások nemcsak a régió térképét rajzolták át, hanem alapvetően befolyásolták a korábbi közös államkeretek közt együtt megélt múlt értelmezését is. A két világháború közötti status quo változatlan fenntartásában érdekelt cseh-szlovák politika, illetve az 1918 elötti állapotok helyreállítását célzó magyar revíziós igények kiszolgálásával a két történetírás viszonyában végletes szembenállások alakultak ki a 10-20. századok közötti közös államkeretek történeti megítélésében.

\section{A poliglott Magyarország öröksége}

Az I. világháború után az 1918 előtti multietnikus Magyar Királyságot és a Mohács után fokozatosan kialakult Habsburg Monarchiát (cseh-)szlovák részről eredendően konfliktusos, csak részben vállalható történeti örökségként kezdték értelmezni. A magyar történetírás pedig a közép-európai népek magyarral jórészt párhuzamos, modern nacionalizmusai számára a magyar állam történetileg kialakult multietnikus kereteit már-már hibátlanként, a békerendszer által szentesített nemzetállami szerkezetnél pedig lényegesen kedvezőbb államjogi konstrukcióként értékelte. A szomszédokká lett szlovák, rutén, román, szerb, horvát, s az erdélyi szász nemzetiség politikai és értelmiségi elitje az 1918-1920 közötti döntésekben az érintett népek önrendelkezési jogának megvalósulását, részleges függetlenségük kivívását látta.

A magyar politikai, kulturális elit részéröl ezzel szemben a nem magyar népek szecessziójában a békekonferencia módszerére jellemző nagyhatalmi diktátum, a történeti kényszer és a „hálátlan nemzetiségek” árulása jelentette az értékelés legfőbb szempontjait. A „rövid 20. század” első felében a kiélezett nacionalista önzés feszültségei, a század második felében pedig a proletár internacionalizmussal és az osztályharcos szemlélettel áthatott „pártos” konfliktusok

REGIO 22. évf. (2014) 1. szám. 156-192. 
tették lehetetlenné az érdemi intézményes együttmüködést. Jóllehet az 1953 óta müködött Magyar-Csehszlovák Vegyes Bizottságban is folytak komoly szakmai viták, készültek értékes elemzések, a pártállami keretek közt a politikai széljáráshoz igazodva hol a szívélyes elvtársi kapcsolatok, hol meg az ideológiai nézeteltérések befolyásolták a kétévente megszervezett ülésszakok munkáját. ${ }^{29}$

Az 1918 előtti multietnikus Magyar Királyság és az 15261918 közötti Habsburg Monarchia az itt élő népek közös hazája volt. Ennek a két államalakulatnak a történetét csak nacionalista és az internacionalista akarnokság és csőlátás próbálhatta kiiktatni a történelemtankönyvekböl, nemzeti kánonokból. Mária Terézia szobrát a csehszlovák államalapítók dühödt nacionalizmusa a pozsonyi koronázó domb helyéröl, Rákosiék nem kevésbé korlátolt internacionalizmusa pedig a budapesti Hösök teréről távolította el. Ezer év közös államiságának minden közös emlékét sikerült az elmúlt száz év alatt lerombolni, relativizálni vagy kisajátítani. A 90 százalékban jobbágyokból álló magyar és szlovák „nép” sem a jobbágyfelszabadítást kimondó pozsonyi országgyülés 1848. márciusi törvényét, sem Ferenc József pátensét nem tekinti közös ünnepnek.

A magyar és a szlovák, illetve „közös” történelem feltárásában 1989 után nyílt először esély tisztázó vitákra, közös módszertani alapokon, elemzési fogalmakon nyugvó, összehangolt kutatásokra, egyáltalán értelmes szakmai párbeszédre. Miközben a nemzetközi akadémiai történetíráson belül mélyreható elméleti, módszertani változások kezdődtek, a demokratikus átalakuláson átesett keletközép-európai nemzetállamok történelempolitikai étvágya, a történeti kutatások irányát, a nemzeti történeti kánonok tartamát befolyásoló ereje, szerepe, az államközi vitákban is a történelmet instrumentalizálni igyekvő törekvése nem csökkent. Ehhez járultak hozzá a sajtószabadság és a politikai pluralizmus gyorsan szárba szökkent vadhajtásaiként a nacionalista mítoszokat felkaroló és egymással szembeni hangulatkeltésre, uszításra felhasználó irányzatok. Egyebek közt ezek a változások teremtették meg azt a 21. század eleji helyzetet, amelyben a szaktörténetírás mellett, helyett a

${ }^{29}$ A kezdetben egyfajta tudománydiplomáciai intézményként müködő vegyesbizottság első korszakáról ld. Szarka László (szerk.): Szomszédok hármas tükörben: A Magyar-Csehszlovák Történész Vegyesbizottság negyedszázada, 1959-1984. Budapest, Akadémiai Kiadó, 1985.

REGIO 22. évf. (2014) 1. szám. 156-192. 
közgondolkodást egyre nagyobb mértékben befolyásolja a köztörténet különbözö irányú, színvonalú termékei, a hun-magyar, az ószláv-ószlovák kontinuitáselméletektől egészen a Magyar Királyság közös államiságának mindkét oldali elvitatásáig, a rendi nemzet és a hungarus identitás értékteremtő szerepének megkérdőjelezéséig.

A korszerü történetírás a 20. század hatvan-hetven éve alatt szakított azzal a historiográfiai szemlélettel és gyakorlattal, amely a múlt maga teljességében nem rekonstruálható társadalmi valóságának - történeti eseményeinek, személyeinek, tényeinek, összefüggéseinek - leírását megpróbálta abszolutizálni és örökörvényüként elfogadtatni. Elfogadja, hogy még ugyanazon nemzeti történetíráson belül is az elemzési fogalmakat a források szakszerü interpretációiban nyomon követhető generációs, módszertani, fogalmi, szemléleti diskurzusok alakítják. Mítosz- és kánonteremtő igyekezetek olvadnak egybe vagy ütköznek a mítoszokat a maguk érvrendszerébe beépítő vagy éppen radiális bírálatnak alávető, a kánonokhoz ragaszkodó vagy éppen újraértelmező törekvésekkel.

Mindeközben a szakmaiság határain belül jól körülírt, szigorú módszertani szabályok, elöre meghatározott tartalmú fogalmak és elfogultságtól, részrehajlástól, tudatos, hangulatkeltő torzításoktól mentes megközelítésre törekvő szakmaiság jelöli ki a szakszerü interpretáció kereteit. Ezzel nagyjából egy időben a történészeknek azzal is szembesülniük kellett, hogy a múlt sohasem csak abban a formájában marad fenn, „ahogy az megtörtént”. ${ }^{30}$ A múltról szóló történetek eredendő sokfélesége részben az adott korban élt különböző érdekeltségü, érintettségü, felkészültségű emberek emlékezetében fennmaradt különbözőségére vezethető vissza. Másrészt a későbbi korok emberei folytathatónak, vállalhatónak, vagy éppen felejtésre ítéltnek, esetleg megtagadandónak tekintették a történéseket.

30 A folyamatos jelentésadásokban résztvevő tudományos, művészeti, vallási, ideológiai tartalmak a közéleti, politikai vitákban sajátos többletjelentéseket kapnak, és ezáltal szimbolikus megformáltságukban társadalmi attitüdök kifejezőivé válhatnak. A nyilvános, politikai diskurzusoknak ez a szimbolikus természete a maga módján a társadalmi, történeti valóság újrarendezését szolgálja.

REGIO 22. évf. (2014) 1. szám. 156-192. 


\section{A közös múlt közös értelmezéseinek nehézségei}

A magyar-szlovák kapcsolatokat az Osztrák-Magyar Monarchia felbomlása, a kelet-közép-európai nemzetállamok létrejötte óta mindkét oldalon alapvetően szintén a szembenállás és a nemzeti létküzdelmek történeti mítoszai, hétköznapi elöítéletek, nemzeti érdekek és önzések, illetve a politikai véleménykülönbségek, konfliktusok alakították. A jó szándékú, de a nemzeti elitek körében többséget sohasem szerző, s emiatt jórészt visszhangtalan közeledési kísérletek sorra megbuktak, vagy el sem jutottak abba a szakaszba, hogy mindkét oldalon érdemben foglalkozzanak velük. A megbékélési próbálkozások ugyanígy fennakadtak a mindkét oldalon felfelhangzó nacionalista szólamokon, történeti fóbiákon vagy éppen történeti fölénytudaton.

A két nép megosztott, egymásnak szembeállított történelme a nemzetállamok és oktatási intézményeik folyamatosan újratermelődő önképe, valamint az 1989-ig ideológiailag gleichschaltolt és államosított historiográfiai hagyomány formájában - ma is jelen van. Az elmúlt bő 20 év kutatási szabadsága és publicisztikai szabadossága igen fontos áttöréseket eredményezett az ideológiailag lefojtott pártállami és államnacionalista történeti diskurzusban. Mindez azonban nem elég ahhoz, hogy a közös történeti értékek, a kis nemzetek sorközösségének a hivatkozási alapjává válhassanak. Ma is az a helyzet, hogy az iskolakönyvekben szereplö, kanonizált történelem sokkal inkább a megosztó és szembeállító vélemények forrása és legitimációs bázisa maradt.

A 21. század eleji magyar és szlovák nemzeti identitás, illetve a szlovák-magyar kapcsolatokat meghatározó történeti háttér meghatározó tényezője a soknemzetiségü történeti Magyar Királyság: a benne megélt közös történelemhez való magyar és szlovák viszonyulás a két nép történeti és mai együttélésének lehetséges értelmezési, interpretációs lehetőségeit tekintve igen sokszínű. A 19-20. századi nemzetállami magatartásformák nyelvi, kulturális megnyilvánulásai és azok társadalomtudományi elemzései ugyan máig befolyásolják

REGIO 22. évf. (2014) 1. szám. 156-192. 
az egymás közti viszonyt, a nemzeti szekértáborok helyett azonban mára már igen színes a kép. ${ }^{31}$

A Magyar-Szlovák Történész Bizottság 2007. évi budapesti és 2008. évi kassai ülésszakán az előző évek sokirányú kezdeményezéseire támaszkodva elkészítette a háromszor hároméves szakaszra tervezett koncepcióját. Ennek első részeként a két nemzet történelmének kulcskérdéseit párhuzamos magyar és szlovák elemzésekkel kezdték el vizsgálni. ${ }^{32}$ Ezzel párhuzamosan a 2003-ban a Történész Bizottság mellett megalakult közös történelemtanári munkacsoport folytatta a közös oktatási modulok formájában elképzelt közös tananyag készítését. ${ }^{33} \mathrm{~A}$ harmadik szakaszban pedig egy történeti olvasókönyv összeállítását tüztük ki célul, amivel ez a három elemböl álló csomag az iskolai tankönyvek kiegészítőjeként jelenhetett volna meg.

Érthetően kapóra jött a Bizottságnak, hogy 2007 nyarán a két ország miniszterelnöke az államközi kapcsolatok egyik mélypontján a történész-együttmüködés támogatását is méltónak tartotta beemelni a kibontakozást szolgáló együttmüködési elképzelések sorába. A Közös múlt - közös jövö - közös projektek fényében címmel közreadott kormányközi emlékeztető 14 pontos együttmüködési csomagja érezhetően a pozitív gesztusokkal kívánták megállítani az akkor éppen eszkalálódó államközi, etnikumközi feszültségeket. Hét évvel később, áttekintve ezt a sokkal inkább kívánságlistának, mintsem megalapozott megbékélési programnak tünő dokumentumot, megállapíthatjuk, hogy jószerivel egyedül a közös munkával megbízott történészbizottság gondolta át felelősséggel, mit is lehet kezdeni a lehetetlenül rövid, félévre szóló felkéréssel, amelynek alapján a kö-

\footnotetext{
31 A csehszlovák, szlovák és magyar nemzetállam két világháború közötti és pártállami időszakának nacionalista kurzusa mellett kétségkívül az 1938-1948 közötti időszak nyíltan etnocentrikus periódusa jelenti a legnegatívabb örökséget. ${ }^{32}$ A Bizottság dokumentációja a Magyar Történelmi Társulat honlapján érhető el: http://www.tortenelmitarsulat.hu/vegyesbizottsag/ulesszakok.php

33 Az elkészült modulok közül a Trianon-modul érhető el a neten keresztül is. Jakab György - ifj. Lator László - Viliam Kratochvíl - Vajda Barnabás: Magyar és szlovák történelemtanárok együttmüködése. Történelemtanítás, (2), 2011. 3. http://www.folyoirat.tortenelemtanitas.hu/wpcontent/uploads/2011/10/02_03_05_Muhely.pdf
}

REGIO 22. évf. (2014) 1. szám. 156-192. 
vetkező három évben a két ország 32 történésze együttmüködését szerény kormányzati támogatási források segítették. ${ }^{34}$

Rövid időn belül az is kiderült, hogy a kormányzati támogatás mögött a két országban különböző politikai kalkulusok, érdekek jelentek meg. Míg a második Gyurcsány-kormány, majd az azt követő második Orbán-kormány szakhatóságai részéről kezdetben a türelmetlen sürgetést, a tanári kézikönyvet pedig a magyar-szlovák megbékélés egyfajta csodavárásfegyverének tapasztaltuk, szlovák részről részben pragmatikusan a szlovák álláspontok kidomborítására törekedtek. Ezt jelezték például a szlovák szerzői csoportban végrehajtott utólagos személyi cserék, illetve az a tény, hogy az első körben a szerzőpárosok magyar és szlovák tagjai által elkészített tanulmányvázlatok közül a szlovák szerzők munkáit - a magyar fél elözetes értesítése nélkül - külön angol nyelvü kiadványban jelentették meg. ${ }^{35}$

A nemzeti szempontok szerint kisajátított, illetve az egymás interpretációit folyamatosan átíró, átértékelö - palimpszeszt - történelemben a felső-magyarországi szlovák régiót érezhetően ma is gyakran egyszerre próbálja szellemi értelemben magáévá tenni a szlovák és a magyar történetírás is. Holott az 1918 előtti multietnikus régiók és a 20-21. századi multietnikus nemzetállamok létezése ténykérdés. A felosztott vagy megosztott történelem ennek ellenére minden évszázadban, minden évtizedben újra és újra kijelöli a nemzeti történelem határait, gyanakodva szemléli a határokon átjárókat, az asszimilációra hajlókat stb.

Rendkívüli jelentőségü tény, hogy 1989 után a szlovák történetírás legfontosabb mühelyeiben elkezdődött az erőteljes kritikai önrevízió, amelynek eredményeképpen ma már a szlovák történészek

\footnotetext{
${ }^{34}$ MTI sajtóközlemény, 2007. június 19.

35 A magyar és szlovák szerzők kiindulópontként rövid 10-10 oldalas vázlatokat készítettek. Ezek elérhetőek a Nógrádi Megyei Levéltár által kezelt kutatási projekt portálon: A magyar és a szlovák történelem kulcskérdései. Párhuzamos tanulmányok, oktatási kiegészitö anyagok - Klúčové otázky slovenských a mad'arských dejín. Paralelné štúdie a metodické modely výučby dejín. (A Magyar-Szlovák Történész Vegyesbizottság munkaanyaga).

http://www.nogradhistoria.eu/id-22-kozos_multunk_kulcskerdesei.html.

A szlovák szerzők rövid vázlatait angolul is megjelentették a pozsonyi História c. folyóirat 2009. 1-2. számában: Key Issues of Slovak and Hungarian History (A View of Slovak Historians) címmel.
}

REGIO 22. évf. (2014) 1. szám. 156-192. 
egységesen elvetik a korábbi dehungarizációs törekvéseket, és a szlovák nemzeti történelem valódi, eredeti kontextusát 1918-ig nem cseh-szlovák egységtörekvésekben, hanem a Magyar Királyságon belül megélt fejlödésben jelölik meg. A magyar államhoz kötődő legmakacsabb és legáltalánosabb szlovák történeti sztereotípiát az ezeréves elnyomás mítosza jelenti, a 18-19. századi filológiai harcokig visszavezethető toposz. Andrej Findor a szlovák történeti mítoszokat kritikai elemzésnek alávető tanulmánykötetben arra a meggyőződésre jutott, hogy „az ezeréves nemzeti elnyomás mítosza a 19. századi sajátos történeti körülmények és a kiélezett nemzetiségi ellentétek produktuma volt. Ez a fajta chiliasztikus történelemfelfogás egybecsengett a 18-19. század fordulóján kialakult nyelvi harcok érvrendszerével”. ${ }^{36}$

Hasonlóképpen nagyon fontos, hogy mindkét történetírásban az elmúlt huszonöt évben megjelentek azok a szemléleti, módszertani újítások, alternatív társadalomtörténeti narratívák, amelyek igyekeznek relativizálni a nemzeti történelmi olvasat kizárólagosságát. A politikatörténeti kutatások fokozatos háttérbeszorulásának megjósolhatóan az lesz az egyik legfontosabb következménye, hogy a nemzetállam és a többségi nemzet legitimitását, történeti létjogosultságát és kizárólagosságra való jogát bizonyítani hivatott történelem egész vonalon kérdőjeleződik meg, s helyette a társadalom, a müvelődés, a hétköznapok történeti narratívái kerülnek a középpontba, lebontva a nemzeti határokat, konfliktusokat.

Érezhetően felerősödőben van a „közös” multietnikus történelem iránti érdeklődés is: részben a nemzetközpontú megközelítések gyengülése, sebezhetősége miatt, másrészt pedig az ,analitikus történelemszemlélet" felerősödése révén. Ugyanakkor a közös múlt az együttélés kétségbevonhatatlan történeti tényei ellenére - ambivalens örökség maradt. A közös államiság hagyományai, értékei két évszázada polémiák és viták tárgyát képezik. 1989 után is csak igen lassan változott a kép. A közös múlt feldolgozásában egyszerre van jelen a közös szellemi, tárgyi, építészeti, intézményi, mentális stb. örökség elismerése és tagadása, megismerése és méltányló beemelése a közgondolkodásba, illetve az attól való elfordulás; mindentől, ami magyar, illetve, ami a történeti Magyarországon belül bizonyít-

${ }^{36}$ Krekovič - Mannová - Krekovičová (red.): Mýty naše slovenské, i. m. 74.

REGIO 22. évf. (2014) 1. szám. 156-192. 
hatóan nem magyar volt. A históriai közös örökség vállalása vagy elutasítása, tanítása vagy félremagyarázása, politikai célok érdekében történő instrumentalizálása és a nyelvi, kulturális különbözőségeken alapuló, szüklátókörű nemzeti történelemszemlélet erőteljesen befolyásolja a nemzeti elöítéletek, sztereotípiák lebontását vagy továbbélését, a történeti megbékélési folyamat sikerét vagy kudarcát.

\section{Szükség van-e magyar-szlovák történelemtankönyvre?}

Minden ellentétes feltételezéssel szemben a francia-német közeledés sok száz kezdeményezése között nem a közös történelemkönyv jelentette a legfontosabb lépést. A közösen megírt Európa-történet mindenesetre azt jelezte, hogy a legnehezebb történeti konfliktusok is leírhatóak és taníthatóak közös tankönyvekből. A 2006 és 2010 között elkészült tankönyvcsomag története 1951-ig nyúlik vissza, amikor a két ország történészeinek konferenciáján ajánlást fogadtak el a két nép kapcsolattörténetének tankönyvi bemutatására. Ezt követően csak az 1980-as években kezdődött el az a rendszeres tankönyvkonferencia- sorozat, amelynek eredményeként 2006-ban Histoire/Geschichte. Europa und die Welt seit 1945 címmel megjelent az első, majd 2008-2009-ben a tankönyvcsalád 2. és 3. kötete is. $^{37}$

A tankönyvcsalád nem a francia és a német, hanem az európai történelmet - annak részeként például az afrikai francia gyarmatosítás és a hidegháborús kelet-európai helyzet sajátosságait - mutatja be a két nagyhatalom konfliktusainak, a két nemzet párhuzamos fejlödésének és a két társadalom sok tekintetben azonos értékrendjének szemszögéből. S mindezt közösen átgondolt, innovatív pedagógiai szempontok alapján: azaz nemcsak szakmai ismereteket közvetít, hanem gondolkodásra ösztönzi a tanulókat az európai történelem sajátosságairól, közös és különböző jegyeiről. Vagy ahogyan az a könyv egyik bemutatóján elhangzott, ez a történelemkönyv a diákoknak megmutatja „a történészszakma követelményeit és határait: a

${ }^{37}$ A francia és a német nyelvű változat egy időben, azonos szöveggel, azonos terjedelemben és formában jelent meg. A német változat bibliográfiai adatai: Histoire/Geschichte - Europa und die Welt vom Wiener Kongress bis 1945. Stuttgart/Leipzig, Ernst Klett Verlag, 2008.

REGIO 22. évf. (2014) 1. szám. 156-192. 
jelent a múlt fényében megvilágítani, hogy a jövőbe tekinthessünk". 38

Ugyanakkor az is tény, hogy a közös tankönyv használata a kezdeti hatalmas lelkesedés után mindkét országban komoly akadályokba ütközik, ugyanis nem sikerült biztosítani sem Franciaországban, sem pedig a tankönyvi, tantervi kérdésekben teljesen autonóm németországi tartományokban a történelemoktatás tankönyvi hátterének átalakítását. Ezzel együtt számtalan tematikai, módszertani, szakmai tanulsága van ennek a kiváló tankönyvcsomagnak. Ezek közül a legfontosabb, hogy csakis megfelelő kormányzati politikai háttérrel, az érdekelt felek teljes egyetértésével lehet belevágni az ilyen kísérletbe. Másrészt olyan tartalmi, pedagógiai, didaktikai szerkezetet kell kialakítani, amely egyszerre felel meg a két ország történelemoktatásában érvényes elvárásoknak, illetve a szaktörténetírás és a történelemoktatás közötti kapcsolatokban megragadható új tendenciáknak, kihívásoknak. S mindeközben törekedni kell arra, hogy a tankönyv anyaga lehetőség szerint minél nagyobb mértékben illeszkedjék be az egyetemes európai történelem korszerüen értelmezett tematikai kontextusába.

A közös tankönyv ugyanis csak abban az esetben vezethet el évtizedek koordinált fejlesztő munkája alapján egyfajta új közös történelemszemlélethez, ha sikerült a közös európai térben, az európai történeti megbékélési folyamatban elhelyezni a határokon átívelö közös történelemoktatást, lett légyen az bilaterális, szomszédok közötti vagy éppen regionális elképzelés. Annál szomorúbban olvassuk, halljuk, hogy 2013-ban sem Franciaországban, sem a német tartományokban nem alkalmazzák rendszerszerúen a közös tankönyvet, ami kétségkívül rámutat a nemzetállami, Németország esetében a tartományi oktatáspolitika konzervativizmusára, nehézkességi erejének hátrányaira is. ${ }^{39}$

\footnotetext{
${ }^{38}$ Kovács Ákos András: A közös történelem és az európai identitás reprezentációjának lehetőségei egy francia-német történelemtankönyvben. In: Új Pedagógia Szemle, 2007. május.

39 Clement de Bravo: Das Buch ist ein Wagnis, BONJOURnalist. In: Ein deutsch-französisches Magazin der Konrad Adenauer Stiftung. http://www.bonjournalist.eu/de/das-buch-ist-ein-wagnis/ (Letöltve 2014. február 10.); A tankönyveket francia és német felhasználók körében végzett vizsgálat alapján értékeli Stefan Seidendorff: Constructing European Citizens? Evaluating
}

REGIO 22. évf. (2014) 1. szám. 156-192. 
Az elmondottakból is érthető, miért választott minden hasonló kísérlet más-más utat: az osztrák-olasz, lengyel-német tankönyvprogramokban a bilaterális konfliktusokat, a rendkívül hatékony délkelet-európai együttműködés nyomán megszületett közös balkáni történelemtanári kézikönyv-sorozatban pedig a régió nacionalizmusainak kölcsönhatásait vizsgálták. ${ }^{40}$

A magyar-szlovák tankönyvviták irodalmában három szempontot érdemes kiemelnünk. Egyrészt azt, hogy a 1960-70-es években - az 1968 körül lezajlott történeti átértékelési kísérletektöl nem függetlenül - a Csehszlovák-Magyar Történész Bizottságban elkezdődött tankönyvelemzés igen gyorsan zsákutcába jutott. A kész tankönyvek etnocentrikus alapozása mindkét országban is megjelent az osztályszempontú, marxista történelemszemléletben. Így azután a kölcsönös történeti sérelmek filológiai kimutatásával legfeljebb a korabeli hivatalos történelempolitika sajátos, kommunista nacionalizmusait lehetett leleplezni, a változások legkisebb esélye nélkül. Arató Endre és Andics Erzsébet szlovák nacionalizmuskritikája uralta a terepet, cseh és szlovák részről viszont a magyar történelmet népi szabadságharcok, forradalmak sorozataként értelmező magyar önképet bírálták hevesen. Minderre azért is érdemes emlékeztetni, mert a rendszerváltás előtti és utáni tankönyvvitákban nagyobb változások nélkül ez a gravaminális megközelítés maradt domináns. ${ }^{41}$

the Integrative Force of Teaching History. In: Niilo Kauppi (ed.): A political sociology of transnational Europe, ECPR University of Essex, Colchester, 2013. 243-264.

40 Teaching Modern Southeast European History: Alternative Educational Materials series. 1-4 works. Series Editor: Christina Koulouri. Thessaloniki, Center for Democracy and Reconciliation in Southeast Europe, 2009. Az első kötet az Oszmán Birodalom történetét, a második a délkelet-európai nemzetek és államok kialakulását, a harmadik a Balkán-háborúk éveit, a negyedik pedig a Balkán-államok II. világháborús történetét dolgozza fel. Az egyes kötetek letölthetők a netröl: http://www.goodreads.com/series/72363-teaching-modernsoutheast-european-history-alternative-educational-mate (Letöltve: 2014. február 10.)

41 Vajda Barnabás: Magyarságkép a csehszlovák történelemtankönyvekben 1950-1993. In: Hornyák Árpád - Vitári Zsolt (szerk.): A magyarságkép a középeurópai tankönyvekben a 20. században. (Kutatási füzetek 14.) Pécs, Pécsi Tudományegyetem, 2009. 259-282; Simon Attila: Közös múlt, egymással feleselő történelem!

REGIO 22. évf. (2014) 1. szám. 156-192. 
A magyar-szlovák viszonyban a reformkortól kezdődően a nyelvharcok mellett a történeti viták is meghatározó szerepet játszottak. Ez részben a szláv-szlovák etnikai-nemzeti és a nagymoráviai állami fejlődés - magyar honfoglalással kapcsolatos konfliktusos, illetve szimbiotikus értelmezése - körüli vitákhoz kapcsolódik. Másrészt a történeti magyar állam és a Habsburg birodalmi keretek multietnikus jellege, a latin háttérbe szorulását követően megjelent német és magyar államnyelvi törekvések jogosultsága váltott ki máig lezáratlan polémiákat. Az 1848/49-es magyar szabadságharc keretei közt megvívott etnikai polgárháborúk, a kiegyezéskori magyar aszszimilációs politika megítélésében éppúgy nagyok a különbségek, mint a Monarchia és a történeti Magyarország felbomlásához vezető belső és külső folyamatok értékelésében. Itt tehát nem a francianémet szomszédság rivális és időről-időre konfliktusokba torkoló párhuzamos fejlődésének, a két világháborúban egymásnak szörnyü veszteségeket okozó ellenfelek bölcs, Európa-orientált megbékéléséről van szó, hanem olyan történetileg kialakult aszimmetrikus viszonyról, amely ugyanazon államon belül a domináns és nem domináns etnikai közösségek hol egymást kiegészítő, támogató, hol meg egymással szembeforduló küzdelméről szólt. Az első világháború geopolitikai fordulatáig mindig egyenlötlen pozíciók ütköztek egymással, 1918 óta viszont az egyenrangú nemzetállami történetírások nemzeti narratíváinak polémiája zajlik. ${ }^{42}$

A két ország iskolai tankönyvpiaca 2013-ig teljességgel eltérő képet mutatott. Szlovákiában a szigorúan centralizált, az oktatási minisztérium illetékes szakmai szervezetei által megrendelt és jóváhagyott egységes és egyetlen tankönyvcsomagból tanult minden diák, még a magyar tannyelvü iskolák tanulói is a szlovák tankönyvek fordítását használták csak. S ebben a tekintetben a közeljövőben

In: Történelemtanítás, 2011/3. http://www.folyoirat.tortenelemtanitas.hu/wpcontent/ uploads/2011/10/02_03_02_Simon.pdf; Kratochvíl, Viliam: Etnikai sztereotípiák a történelemtankönyvek „mi” és „ők” konstrukcióiban. In: Történelemtanítás, 2011/3. http://www.folyoirat.tortenelemtanitas.hu/wp-content/ uploads/2011/10/02_03_03_Kratochvil.pdf

42 Jakab György: Lehet-e közös magyar-szlovák történelemkönyvet írni? In: Hornyák Árpád - Vitári Zsolt (szerk.): A magyarságkép, i. m. 321-350.

REGIO 22. évf. (2014) 1. szám. 156-192. 
sem várható változás. ${ }^{43}$ Magyarországon ettől teljesen eltérő módon a legújabb tankönyvreformnak a 2014/15-ös tanévben való bevezetéséig 6-7 tankönyvcsomagból választhattak az iskolák, illetve a történelemtanárok. A magyarországi nemzeti kisebbségek tanulói saját népismereti tankönyveikből tanulhattak történelmet, ami csak részben valósult meg a szlovákiai magyarok esetében a nem állami megrendelésre készült, de a minisztérium által utólag jóváhagyott, $A$ magyar nép története c. tankönyvnek köszönhetően.

Jórészt éppen ezek az okok és a két országban élő kisebbségek közös történelem iránti igénye jelentik a késztetést a magyarszlovák közös múltfeltárásra és az oktatásra is alkalmas közös tananyagok előállítására, egyszersmind ezek a tényezők merülnek fel megoldhatatlan akadályként is a közös történelemkép kialakításában. Természetesen nem ez az egyetlen paradoxon a két nemzet kapcsolatrendszerében. Elég csak arra utalnunk, hogy a közös államiság évszázadai alatt felhalmozódott tömérdek közös kulturális, gazdasági, emberi, szellemi érték, szimbólum, történeti emlékezeti hely ma is inkább a megosztás és a szembenállás érvei közt szerepel. Jól példázza ezt a két nemzetállam kettős keresztes címerének hasonlósága - a két nemzet történeti közelségének, rokonságának páratlan szimbóluma. Mégis a címerrel kapcsolatos vélemények nem az értékközösség tudatosítását szolgálják, hanem leggyakrabban a vádaskodásig terjedő birtokviták logikáját idézik.

Befejezésül talán érdemes jelezni: haszontalanul felesleges minden olyan múltba nézés, minden olyan etnocentrikus alapozású szomszédságtörténeti vita, amely tagolatlan nacionalista képletekben gondolkodik a közös múltról és a szomszéd országok történetírásairól. Amikor azt a bizonyos gerendát szem elől tévesztve úgy kívánnak egyesek rendet rakni a közös állami múlt és a kétszáz-háromszáz

\footnotetext{
${ }^{43}$ Vajda Barnabás - Deák Irén - Elek József: Miért elfogadhatatlanok számunkra a szlovákból fordított történelemtankönyvek? In: Történelemtanítás, 2013/2. http://www.folyoirat.tortenelemtanitas.hu/wpcontent/uploads/2013/07/04_02_11_Vajda_Deak_Elek.pdf

${ }^{44}$ Simon Attila - Kovács László: A magyar nép története - A honfoglalástól a szatmári békéig. Az alapiskolák 7. osztálya és a nyolcéves gimnáziumok 2. osztálya számára. Dunaszerdahely, Lilium Aurum, 1997; Uők: A magyar nép története 1711-töl 1918-ig. Dunaszerdahely, Lilium Aurum, 1998; Uők: A magyar nép története a 20. században. Dunaszerdahely, Lilium Aurum, 2000.
}

REGIO 22. évf. (2014) 1. szám. 156-192. 
éve természetüknél fogva elkülönülten, egymásnak feszülve fejlődő nacionalizmusok nehezen szétszálazható összefüggéseiben, hogy utólag kívánják megszabni a párhuzamos nemzetépítések nekünk tetsző szabályait. Helyette olvasni kellene „szlávul”, hogy a szlovák, rutén, ukrán, szerb, horvát, szlovén nemzet múltjáról, történetírásról tisztességgel és megfelelő ismeretek alapján képet tudjunk alkotni, s ahol nyilvánvaló történelemhamisítás történik, határozottan vitába szállni.

Merthogy tény, a szomszédos historiográfiák - a magyarhoz hasonlóan ma is folyamatosan újraértelmezik - saját múltjukat. Ennek a szakmának ugyanis ez a legfontosabb dolga. A Szlovák Történeti Lexikon föszerkesztője, a besztercebányai Bél Mátyás Egyetem történelemprofesszora, a magyar-szlovák oktatási segédkönyv egyik szerzője, Dušan Škvarna például A Magyar Királyság nehéz tehertétele címmel írott, itthon visszhangtalan maradt esszéjében a szlovák történeti közgondolkodás fenntartásainak okait a közös magyarországi történelem elfogadásával szemben az alábbi, tartósan rögzült auto- és heterosztereotípiákban jelöli meg: A szlovákság és az általa lakott terület mindig is elmaradott részét alkotta a közös államnak. Ennél fogva a mai Szlovákia területe és történelme marginális jelenségnek számítottak. Mindennek okaként pedig a kedvezötlen történelmi körülményeket szokás emlegetni. Ezek közt a sokszázéves elnyomás, s annak megtestesítöiként Magyarország és a magyarok játszanak kiemelt szerepet. Mindez egyszerre tartja életben a mai szlovák közvélemény egy részének magyarellenességét, illetve a történelem iránti szlovák érdektelenségét. ${ }^{45}$ A felsorolt sztereotípiákat elemezve és cáfolva Škvarna joggal mutat rá arra, hogy a szlovák történelem magyar(országi) örökségének racionális feldolgozását a szlovák és magyar történeti önzés nacionalista reflexei együtt tették nehézzé. A hungarus világképek már a 19. század folyamán megkoptak. Helyükbe a 19. századi nemzeti romantika reformkori és 1848as toposzai, dualizmuskori nacionalista olvasatai léptek. A történeti magyar állam megszünése pedig teret adott a közös történelem és a

\footnotetext{
${ }^{45}$ Škvarna, Dušan: Bremeno Uhorska v našich dejinách. Impulz. Revue pre modernú katolícku kultúru. (8) 2012. 2.

http://www.impulzrevue.sk/article.php?842
}

REGIO 22. évf. (2014) 1. szám. 156-192. 
benne rejlő közös értékvilágok magyar nemzeti kisajátításának, illetve szlovák megtagadásának.

Kérdés persze, lehet-e a magyar nemzeti történelem kánonját a 21. század eleji demokratikus nemzetállam keretei közt úgy alakítani, hogy abban a - soknemzetiségü történeti magyar állam területén élő - többi nemzet történelme is méltó helyet kapjon. Vagy máris eldőlt, hogy a napjaink köztörténetében lábra kapó neonacionalista törekvések a két világháború között intézményesült nemzetállami konfrontáció irányvonalát kívánják folytatni. S ez már nem csupán a történészek és lektorok felelőssége. A kánonok újraírásával foglalkozó történelempolitika alakítóinak azonban mindenütt számolniuk kell azzal, hogy minden - a kizárólagosság erővonalai mentén elképzelt nemzeti mesternarratívával mindenki magát teszi szegényebbé. S közben céltáblát és muníciót is kínál a szomszédvárak hasonló logika alapján müködő mesterlövészeinek.

A modern és kivált a posztmodern nemzeti emlékezetben természetesen megkülönböztetetten fontos, semmivel sem pótolható helye van a népek, csoportok, régiók, családok történetének. S ennek megfelelően megkerülhetetlenül az új kánonokban is jelen lesz a sérelmekre és jóvátételi igényekre épülő történelemkép. A középeurópai nemzetek 21. századi kollektív emlékezetében azonban egymás elfogadása ma már minimális elvárás. A nemzeti értékrendek közös előzményeinek, előképeinek megismerése pedig az olyannyira szükséges térségi összefogásnak éppoly fontos előfeltétele, mint a közös nyelv hiányában is megteremthető beszédközösség.

\section{IRODALOM}

Ablonczy Balázs: Trianon-legendák. Budapest, Jaffa Kiadó, 2010.

Ábrahám Barna (szerk.): Magyar-szlovák terminológiai kérdések. (Pons Strigoniensis Studia IX.) Esztergom - Piliscsaba, Pázmány Péter Katolikus Egyetem, 2008.

Balassa Zoltán: Két nemzet a Kárpát-medencében. A szlovákok története. Kassa-Budapest, 2009. (magánkiadás)

REGIO 22. évf. (2014) 1. szám. 156-192. 
Balogh Margit (szerk.): Felekezetek, egyházpolitika, identitás Magyarországon és Szlovákiában 1945 után = Konfesie, cirkevná politika, identita na Slovensku a v Mad'arsku po roku 1945. (Ford. Avar Hajnalka, Galina Šándorová.) (Historia Slovaco-Hungarica - Hungaro-Slovaca 2.) Budapest, Kossuth, 2008.

Botto, Julius: Krátka história Slovákov. Turčiansky Sv. Martin, Knihtlačiarsky účastinársky spolok, 1914.

Bravo, Clement de: Das Buch ist ein Wagnis, BONJOURnalist. In: Ein deutsch-französisches Magazin der Konrad Adenauer Stiftung. http://www.bonjournalist.eu/de/das-buch-ist-ein-wagnis/

Csukovits Enikö - Lengyel Tünde (szerk.): Bártfától Pozsonyig. Városok a 13-17. században. Budapest, MTA TTI, 2005. Ugyanez szlovákul: Csukovits Enikö - Lengyel Tünde (red.): Z Bardejova do Prešporku. Spoločnost' súdnictvo a vzdelanost'v mestách v. 13.-17. storočí. Prešov-Bratislava, 2005

Demmel József: Pánszlávok a kastélyban. Justh József és a szlovák nyelvü magyar nemesség elfeledett története. Budapest, Kalligram, 2014.

Dudeková, Gabriela: Etnické stereotypy v historickom výskume. Forum Historiae, 2012/2. http://forumhistoriae.sk/02-2012

Farkas Géza: Szlovákia-ügy. Rendhagyó megfontolások. In: Magyar Hüperion, 2013. Digitálisan elérhető a felvidéki hírportálon: http://www.felvidek.ma/images/stories/_esemenyek/2014/02/MH II_1_Farkas_G._2.pdf

Fedinec Csilla - Vehes Mikola (szerk.): Kárpátalja 1919-2009: történelem, politika, kultúra. Budapest, Argumentum, 2009; Ugyanez ukránul: М. Вегеш - Ч. Фединець (eds.): Закарпаття 1919-2009 років: історія, політика, культура. Ужгород, Видавництво «Ліра», 2010. 
Fuglestad, Fin: The Ambiguities of History: The Problem of Ethnocentrism in Historical Writing. Academic Press, Oslo, 2005.

Gyáni Gábor: A mai magyar történetírás dilemmái. In: Uő Relatív történelem. Budapest, Typotex, 2007. 285-290.

Gyáni Gábor: Kollektív emlékezet vagy történetírás? Mire emlékszünk? A közösségi memória szelektivitása Magyarországon és a nagyvilágban. A Történelemtanárok Egyletének országos konferenciája.

http://www.tte.hu/toertenelemtanitas/toertenelemtanarokorszagos-konferenciaja/7843-gyani-gabor-kollektiv-emlekezetvagy-toertenetiras

Histoire/Geschichte - Europa und die Welt vom Wiener Kongress bis 1945. Stuttgart/Leipzig, Ernst Klett Verlag, 2008.

Holec, Roman: Trianoni rituálék, avagy gondolatok a magyar historiográfia egyes jelenségeiről. In: Fórum - Társadalomtudományi Szemle, (12) 2011. 4. 109-132.

Hóman Bálint (szerk.): A Magyar történetírás új útjai. Budapest, Magyar Szemle Társaság, 931.

Horváth, Michael: Vorwort. In: Geschichte von Ungarn von Ignaz Aurelius Fessler. Leipzig, 1867.

Iványi Béla: Pro Hungaria Superiore. Felsömagyarországért. Debrecen, Ref. Egyházkerület ny., 1919.

Jakab György - ifj. Lator László - Viliam Kratochvíl - Vajda Barnabás: Magyar és szlovák történelemtanárok együttmüködése. Történelemtanítás, (2), 2011. 3.

http://www.folyoirat.tortenelemtanitas.hu/wp-

content/uploads/2011/10/02_03_05_Muhely.pdf

REGIO 22. évf. (2014) 1. szám. 156-192. 
Jakab György: Lehet-e közös magyar-szlovák történelemkönyvet írni? In: Hornyák Árpád - Vitári Zsolt (szerk.): A magyarságkép a közép-európai tankönyvekben a 20. században. (Kutatási füzetek 14.) Pécs, Pécsi Tudományegyetem, 2009. 321-350.

Kántor Zoltán: Szöveggyüjtemény a nemzeti kisebbségekröl. Budapest, Rejtjel Kiadó, 2005. 45-48.

Kováč, Dušan: Szlovákia története. Pozsony, Kalligram 2001.

Kovács Ákos András: A közös történelem és az európai identitás reprezentációjának lehetőségei egy francia-német történelemtankönyvben. In: Új Pedagógia Szemle, 2007. május.

Kratochvíl, Viliam: Etnikai sztereotípiák a történelemtankönyvek „mi” és „ő” konstrukcióiban. In: Történelemtanítás, 2011/3. http://www.folyoirat.tortenelemtanitas.hu/wp-content/ uploads/2011/10/02_03_03_Kratochvil.pdf

Krekovič, Eduard - Mannová, Elena - Krekovičová, Eva (red.): Mýty naše slovenské. Bratislava, AEP, 2005.

Pechány Adolf: A magyarországi tótok. Miskolc, Felsőmagyarországi Minerva, 2000.

http://www.sulinet.hu/oroksegtar/data/magyarorszagi_nemzetiseg ek/szlovakok/a_magyarorszagi_totok/pages/020_pehany_adolf_e latrajza.htm

Plamenat, John: A nacionalizmus két típusa. In: Bretter Zoltán Deák Ágnes (szerk.): Eszmék a politikában: a nacionalizmus. Pécs, Tanulmány Kiadó, 1995. 56-57.

Podhradszky György: A tótok lakta Felföld politikai és kultúrgeográfiája (Függelékül a kérdés bibliográfiája). Budapest, Stúdium, 1924.

Romsics Ignác (szerk.): Mítoszok, legendák, tévhitek a 20. századi magyar történelemröl. Budapest, Osiris, 2003.

REGIO 22. évf. (2014) 1. szám. 156-192. 
Romsics Ignác: Clio büveletében. Magyar történetírás a 19-20. században - nemzetközi kitekintéssel. Budapest, Osiris, 2011.

Seidendorff, Stefan: Constructing European Citizens? Evaluating the Integrative Force of Teaching History. In: Niilo Kauppi (ed.): A political sociology of transnational Europe. ECPR University of Essex, Colchester, 2013. 243-264.

Simon Attila - Kovács László: A magyar nép története - A honfoglalástól a szatmári békéig. Az alapiskolák 7. osztálya és a nyolcéves gimnáziumok 2. osztálya számára. Dunaszerdahely, Lilium Aurum, 1997.

Simon Attila - Kovács László: A magyar nép története 1711-től 1918-ig. Dunaszerdahely, Lilium Aurum, 1998.

Simon Attila - Kovács László: A magyar nép története a 20. században. Dunaszerdahely, Lilium Aurum, 2000.

Simon Attila: Közös múlt, egymással feleselö történelem! In: Történelemtanítás, 2011/3. http://www.folyoirat.tortenelemtanitas.hu/wp-content/ uploads/2011/10/02_03_02_Simon.pdf

Škvarna, Dušan: Bremeno Uhorska v našich dejinách. Impulz. Revue pre modernú katolícku kultúru. (8) 2012. 2. http://www.impulzrevue.sk/article.php?842

Šutaj, Štefan - Szarka László (red.): Regionálna a národná identita $v$ mad'arskej a slovenskej histórii 18.-20. storočia = Regionális és nemzeti identitásformák a 18-20. századi magyar és a szlovák történelemben. (Historia Slovaca-Hungarica - Hungaro-Slovaca 1.) Prešov: Universum, 2007.

Šutaj, Štefan: Szlovák-magyar történelmi párhuzamok és konfliktusok (a nemzeti történelmek közép-európai kontextusban) avagy a 
közös szlovák-magyar szövegek írásáról. In: Korridor, 2014/1. http://korridor.eu/issue/elso-evfolyam-2014-1-szam/

Szabó Miklós: Politikai kultúra Magyarországon 1896-1986. Atlantis, Budapest, 1989. 236-237.

Szarka László (szerk.): Szomszédok hármas tükörben: A MagyarCsehszlovák Történész Vegyesbizottság negyedszázada, 19591984. Budapest, Akadémiai Kiadó, 1985.

Szarka László: Felföld, Felvidék, Szláv Kerület - Slovensko. Adalékok a felföldi magyar-szlovák nemzeti térkijelölés XVIII-XIX. századi történetéhez. In: Papp Richárd - Szarka László (szerk.): Bennünk élö múltjaink. Történelmi tudat - kulturális emlékezet. Zenta, Vajdasági Magyar Müvelődési Intézet, 2008. 143-161.

Szarka László: Párhuzamos jelenségek a magyar és szlovák történetírásban, köztörténetben. In: Történelmi Szemle, (54.) 2012. 3. 469-490.

Teaching Modern Southeast European History: Alternative Educational Materials series. 1-4 works. Series Editor: Christina Koulouri. Thessaloniki, Center for Democracy and Reconciliation in Southeast Europe, 2009.

Tőkéczki László: Egy posztmodern nemzetépítés és identitás alakítás Európa közepén. In: Hitel 2013/12. 69-72.

http://www.hitelfolyoirat.hu/sites/default/files/pdf/10-tokeczki.pdf

Vajda Barnabás - Deák Irén - Elek József: Miért elfogadhatatlanok számunkra a szlovákból fordított történelemtankönyvek? In: Történelemtanítás, 2013/2.

http://www.folyoirat.tortenelemtanitas.hu/wpcontent/uploads/2013/07/04_02_11_Vajda_Deak_Elek.pdf

Vajda Barnabás: Magyarságkép a csehszlovák történelemtankönyvekben 1950-1993. In: Hornyák Árpád - Vitári Zsolt (szerk.): A magyarságkép a közép-európai tankönyvekben a 20. században. 
(Kutatási füzetek 14.) Pécs, Pécsi Tudományegyetem, 2009. 259282.

Vörös László: Analytická koncepcia versus národné dejiny „Národ” ako sociálna reprezentácia. Pisa, Pisa University, 2009.

Zahorán Csaba: a Trianon-jelenség pozsonyi tükörben. Válasz Roman Holec Trianoni rituálék, avagy gondolatok a magyar historiográfia egyes jelenségeiről címü cikkére. In: Historický časopis, 58. évf. 2010. 2. sz. 291- 312.

REGIO 22. évf. (2014) 1. szám. 156-192. 